\title{
Analisis Performance Central Prosessing Unit (CPU) Realtime Menggunakan Metode Benchmarking
}

\section{An Analysis of Performance Central Processing Unit (CPU) for Real Time Using Benchmarking Method}

\author{
Yunanri.W' ${ }^{1}$ Ammar Fauzan ${ }^{2}$, Ahmad Yani ${ }^{3}$, Muhammad Abdul Aziz \\ ${ }^{1}$ Universitas Teknologi Sumbawa, Indonesia \\ ${ }^{2}$ Akademi Manajemen Informatika dan Komputer PGRI Kebumen, Indonesia \\ ${ }^{3}$ Sekolah Tinggi Teknologi Industri Bontang, Indonesia \\ ${ }^{4}$ Universitas Maarif Nahdatul Ulama Kebumen, Indonesia
}

\section{Article Info}

Article history:

Received, 29 Maret 2021

Revised, 15 Mei 2021

Accepted, 17 Mei 2021

\section{Kata Kunci:}

Analisis

Hardware

$C P U$

Benchmark

Realtime

Keywords:
Analysis
Hardware
CPU
Benchmark
Realtime

\begin{abstract}
ABSTRAK
Perkembangan teknologi semakin berkembang cepat baik dari performa, grafik, bandwidth dan lain-lainnya sehingga di perlukanlah sebuah piranti dengan kemampuan yang handal dalam membantu kinerja yang lebih baik terutama pada central prosessing unit. Pada dunia bisnis, saat ini telah memfaatkan kemajuan teknologi informasi demi kelancaran kerja dibidang yang digeluti baik sekala kecil maupun sekala besar. Metode yang digunakan benchmarking merupakan suatu proses mengidetifikasi terhadap hardware dan proses suatu tolak ukur sebuah performa yang diharapkan. Adapun langkah pengujian melakukan evalusi kinerja central prosessing unit (CPU) yang dilakukan pada kinerja hardware atau perangkat keras baik prosessor, ram, vega dan lain sebagainya. Hasil pengujian yang dilaksanakan pada cental prosessing unit (CPU) penggunaan ram oleh prosessor i3 sebesar $3.1 \mathrm{~Gb}, \mathrm{GPU} 3 \%$, Disk uses $1 \%$, penggunaan network atau jaringan 7.7 Mbps, penggunaan power suplay very low. Prosessor i5 sebesar $4.2 \mathrm{~Gb}, \mathrm{GPU} 0 \%$, Disk uses 0\%, penggunaan network atau jaringan $7.7 \mathrm{Mbps}$, penggunaan power suplay low. Prosessor i7 sebesar $2.5 \mathrm{~Gb}$, GPU 9\%, Disk uses 9\%, penggunaan network atau jaringan $104 \mathrm{Kbps}$, penggunaan power suplay high.
\end{abstract}

\section{ABSTRACT}

Technological developments are growing rapidly both in terms of performance, graphics, bandwidth, and others so we need a device with reliable capabilities to help better performance, especially in the central processing unit. In the business world, current advances in information technology have been taken advantage of for the smooth running of work in the fields they are engaged in both on a small and large scale. The method used by benchmarking is a process of identifying hardware and the process of measuring an expected performance. The test step is to evaluate the performance of the central processing unit (CPU) which is carried out on the performance of hardware or hardware both processor, RAM, vega, and so on. The results of tests carried out on the central processing unit (CPU), the use of ram by the i3 processor is 3.1 Gb, GPU 3\%, disk uses 1\%, network or network usage is 7.7 Mbps, the use of power supply is very low. The i5 processor is $4.2 \mathrm{~Gb}$, GPU 0\%, Disk uses 0\%, network usage or network usage is 7.7 Mbps, low power supply usage. The i7 processor is 2.5 Gb, GPU 9\%, Disk uses 9\%, network usage is $104 \mathrm{Kbps}$, high power supply usage.

This is an open access article under the CC BY-SAlicense.

\footnotetext{
Penulis Korespondensi:

Yunanri.W,

Program Studi Teknik Informatika,

Universitas Teknologi Sumbawa, Indonesia

Email: yunanri.w@uts.ac.id
} 


\section{PENDAHULUAN}

Di era globalisasi ini semua bidang dituntut harus mengikuti perkembangan zaman dimana semua nya menggunakan spektrum dengan kemampuan tinggi baik pada penggunaan software aplikasi maupun pada piranti perangkat keras atau hardware nya membutuhkan performa, grafik, bandwidth dan lain-lainnya. Dimana tujuan penelitian ini akan membahas central prosessing unit (CPU). Pada dunia bisnis, saat ini telah memfaatkan kemajuan teknologi informasi demi kelancaran kerja dibidang yang digeluti baik sekala kecil maupun sekala besar[1].

Seorang programmer atau IT security membutuhkan performa central prosessing unit (CPU) yang mumpuni dalam menunjang kinerja jobdesk masing-masing. Seorang pengiat IT membutuhkan performa tinggi dalam menunjang kerja yang cepat dan akurat yang ditampilkan pada pengujian seperti pada gambar[2][3][4].

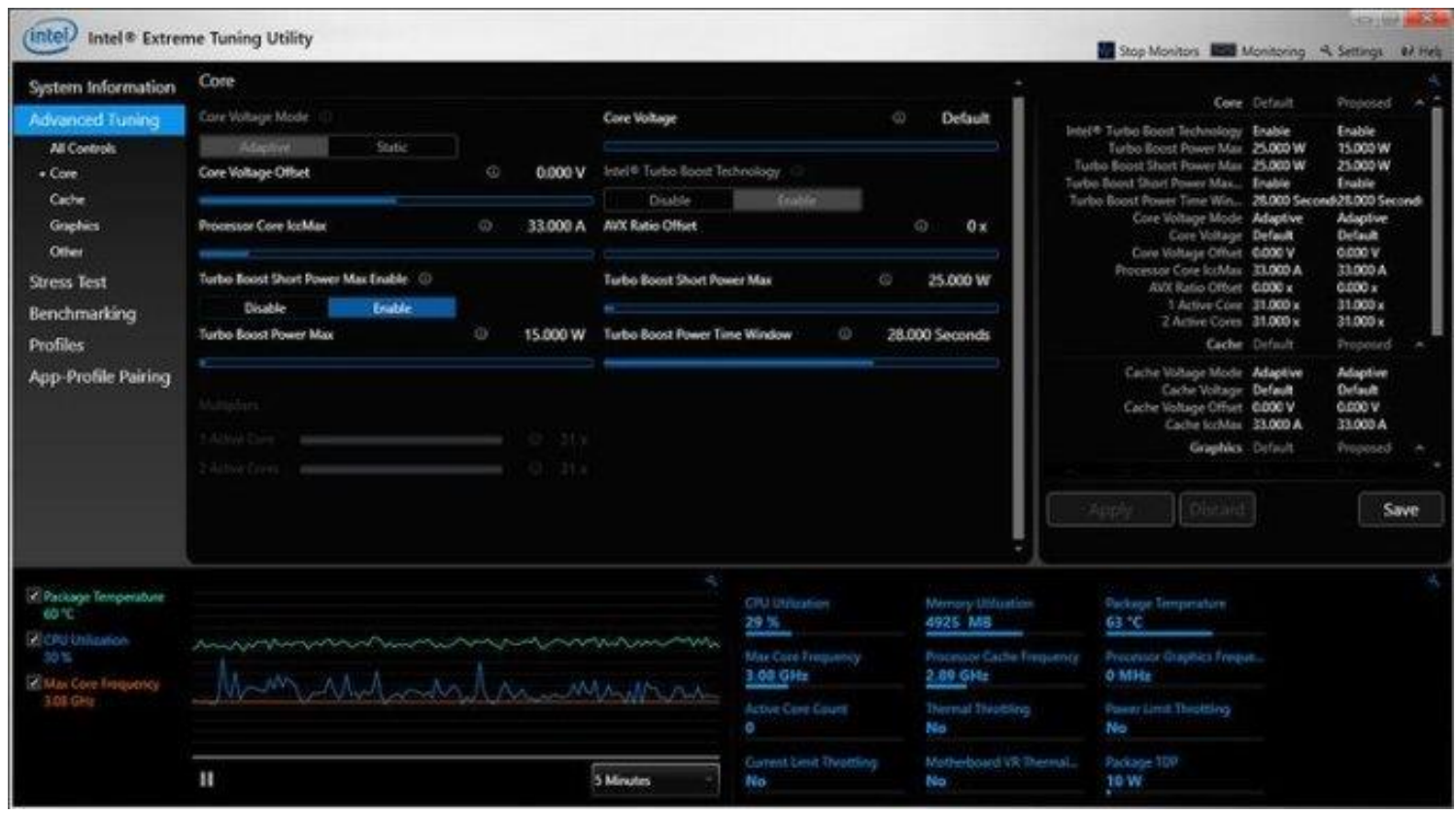

Gambar 1. Hasil pengujian pada central prosessing unit (CPU) Intel Tunning Utility

Gambar 1. Menjelaskan Benchmark yang dilakukan oleh pasar menunjukkan persaingan kemampuan dari setiap prosessor baik dari perusahaan Intel, dapat disimpulakan pemenang akan performa dan kemampuan dari grafik dimenangkan oleh perusahaan AMD Ryzen 7- 3700x, akan tetapi harga nya masih mahal dipasar global.

\section{METODE PENELITIAN}

Benchmarking merupakan sebuah pengujian pada piranti perangkat keras atau hardware. dan proses. Hardware sebagai yang di uji dengan kemampuan kinerja pada central prosessing unit (CPU) dimana menjadi tolak ukur, Metode evalusi kinerja central prosessing unit yang dilakukan menggunakan metode benchmark meliputi pengujian dan perbandingan kinerja terhadap: Pengujian pada hardware yang akan di benchmark, Meniliai kemampuan perangkat keras, Tujuan di lakukannya pengujian pada perangkat keras, Pengumulan informasi data dan Analisa hasil Menetapkan pilihan akhir. Metode penelitian mengacu pada Waterfall. 


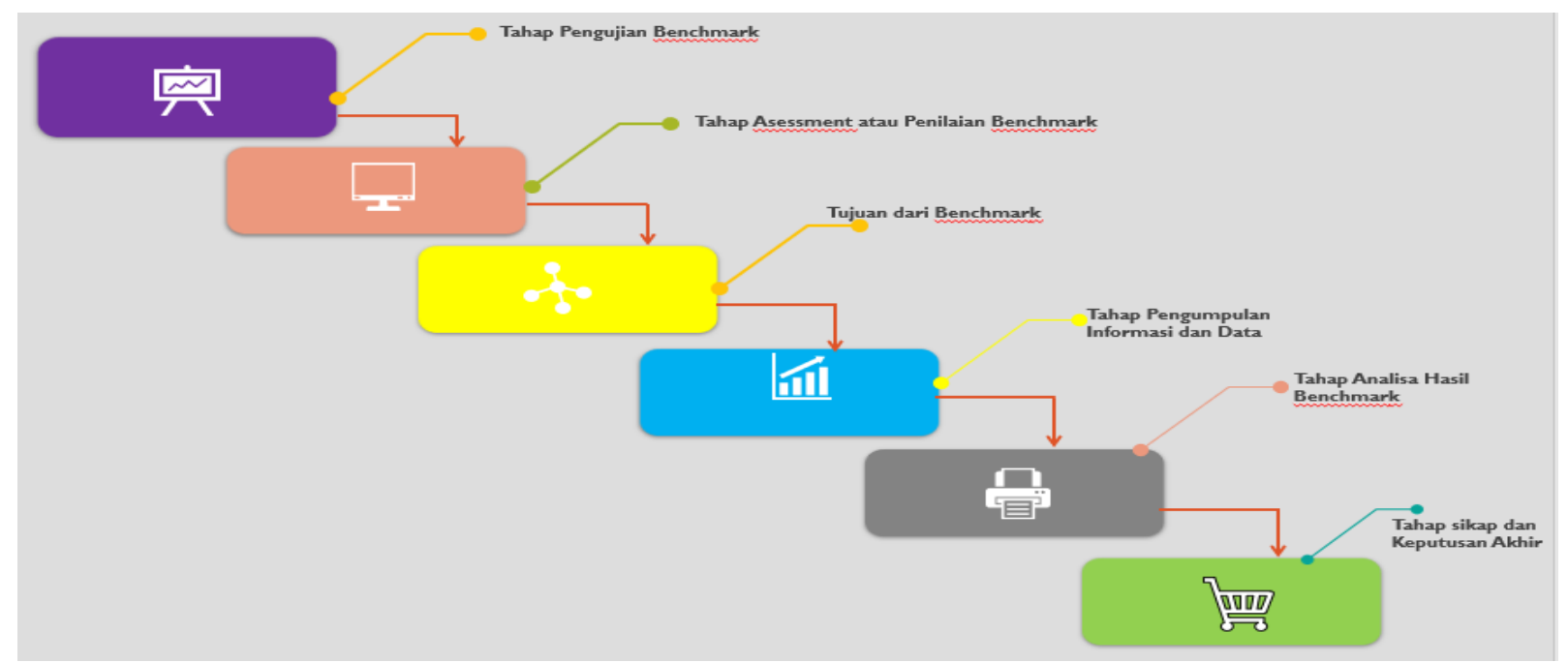

Gambar 2. Metodologi waterfall assessment pada bencmark central prosessing unit (CPU).

Merupakan metode yang digunakan sebagai acuan terstuktur sebagai proses penyusunan dalam merumuskan cakupan dari penelitian " Analisis performance central prosessing unit (CPU) realtime menggunakan metode bechmarking". Sebagaimana yang ditampilkan pada gambar 2.

\section{Tahapan-tahapan pengujian serta asessment terhadap perangkat keras atau hardware antara lain:}

1. Pengujian pada hardware atau perangkat keras dibenchmark, Benchmark dapat dilakukan selama mengikuti aturan prinsip: pengujian, assessment, Tujuan, analisa baik informasi dan data. Suatu proses yang dilakukan sebagai barometer terhadap keputusan akhir yang diambil.

2. Asessment atau penilaian, Adanya standar yang digunakan dalam melakukan pengujian benchmark, mencakup hal-hal seperti pada penelitian ini, kita akan menetukan performance dari hardware yang kita pilih yaitu prosessor core i3, i5, i7. Dan ada pula hal-hal lain yang dapat di benchmark antara lain GPU, RAM, Main Board, Powersuplay dan lain-lain.

3. Tujuan dari benchmark, Menentukan organisasi atau perusahaan menjadi pilihan benchmarking ini. Pertimbangan yang perlu adalah tentu memilih perangkat keras atau hardware yang terbaik, efisien, low cost [5].

4. Pengumpulan Informasi dan data, Informasi serta data yang telah di peroleh dari hasil pengujian pererangkat keras akan di simpan untuk selanjutkan akan di teruskan pada tahap analisa hasil, dengan tujuan akan melakukan observasi pengkajian apakah bisa di lanjutkan ketahap akhir[6].

5. Analisa hasil, Analisa hasil memiliki tujuan yaitu untuk melakukan perhitungan dan observasi bersama tim kerja untuk menilai apakah masuk dalam standar yang diinginkan[7][8].

6. Menetapkan pilihan akhir,Melakukan pemetaan dari hasil seluruh pengujian yang telah dilakukan agar bisa memutuskan terhadap apa menjadi standar hasil yang di harapkan.

\section{Pengujian yang akan dilakukan antara lain :}

1. Pengujian Sistem analisis menggunakan central prosessing unit (CPU) Prosessor core i3.

2. Pengujian Sistem analisis menggunakan central prosessing unit (CPU) Prosessor core i5.

3. Pengujian Sistem analisis menggunakan central prosessing unit (CPU) Prosessor core i7. 


\section{HASIL DAN ANALISIS}

Simulasi pengujian Benchmark dilakukan pada central prosessing unit (CPU).

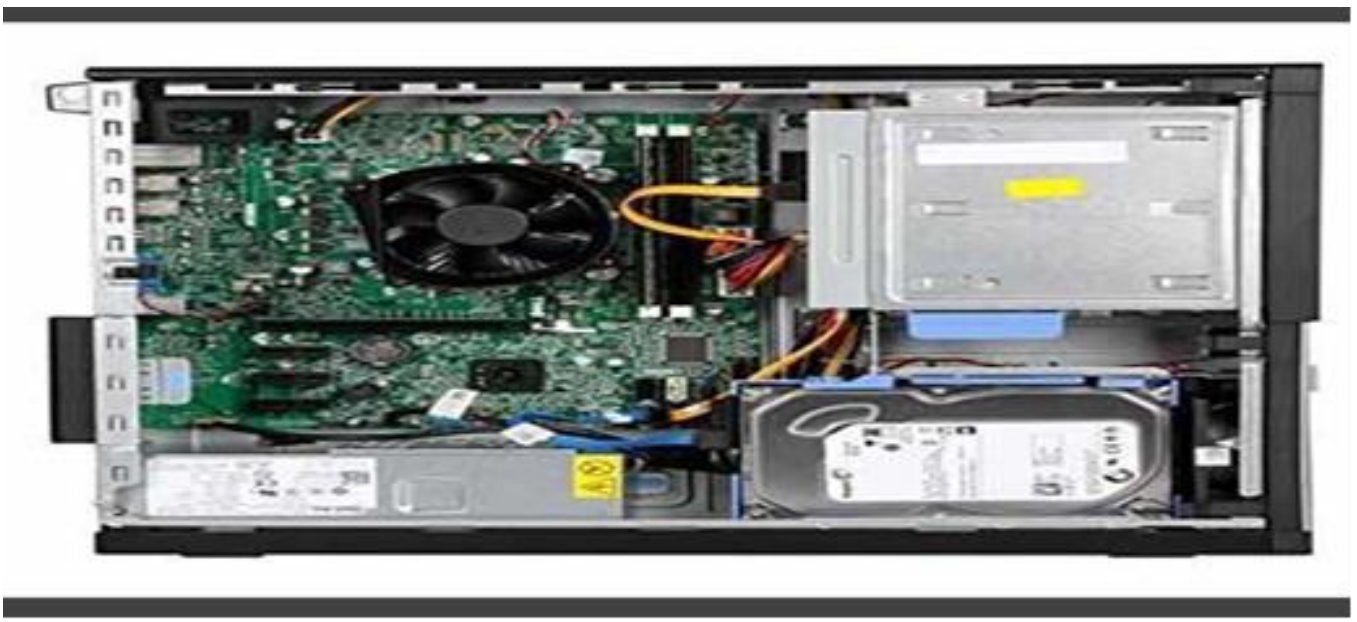

Gambar 3. Central Prosessing Unit (CPU).

Menunjukkan cental prosessing unit (CPU) terdiri dari beberapa perangkan komponen pendukung antara lain: Prosessor, Motherboard, Random Acces Memory, Hardisk, Video Grafik, DVD Room sebagaimana di tunjukan pada gambar 3.

\subsection{Pengujian pada perangkat keras yang akan di bechmark.}

Fungsi dari benchmark adalah pengujian terhadap perangkat keras pada central prosessing unit (CPU). Dimana komputer merupakan alat pengolah data yang sudah di tanamkan sebuah prosedur yang telah dirumuskan [9]. Komputer diciptakan dengan tujuan untuk melakukan perhitungan arimetika dan tanpa ada mesin pembantu [10]. Seiring perkemabngan sampai sekarang komputer sudah melalui berbagai tahapan seperti menghitung, mengetik, mendesain, editing video, monitoring tafik lalulintas jaringan dan masih banyak lagi kegunaan dari perangkat komuter.

\subsection{Penilaian atau Asessment.}

Adapun objek penelitan yang dilakuakan pada software aplikasi antara lain: MS. Office 2016, CorelDraw 2017, Winamp (media player mp3 dan $m p 4$ ), Media player clasic, Anti virus ES - ET ( internet security).

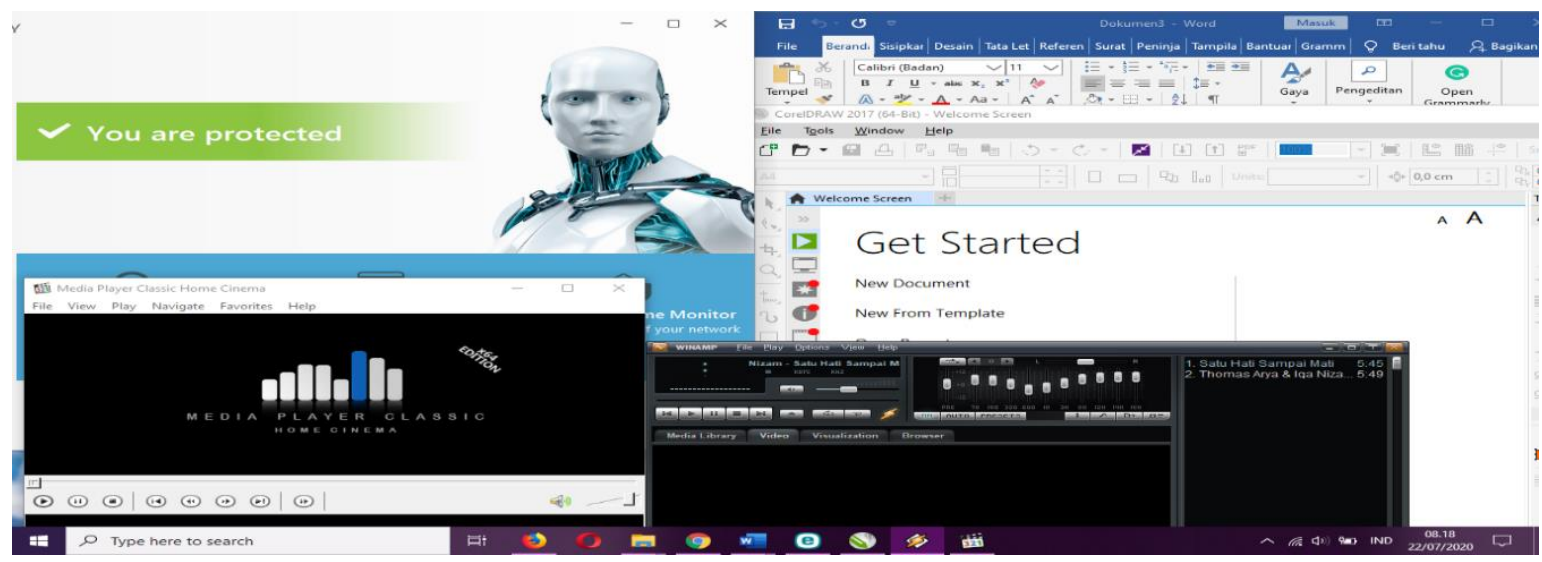

Gambar 4. Central Prosessing Unit (CPU).

Simulai pengujian pada bebrapa item software aplikasi antaralain : Microsoft Office 2016, Coreldraw 3, Winap mediaplayer mp3 dan mp4, media player clasic, antivirus ES-ET edisi Internet Security. yang ditampilkan pada gambar 4. 
3.3. Tujuan dari benchmark.

Peningkatan Mutu menentukan kemampuan dari central prosessing unit (CPU), menjadi acuan utama dalam pengambilan keputusan[11]. Akan menjadi sorotan baik atau buruk nya kemampuan dari sebuah prosessor yang memiliki kemampuan handal yang dapat digunakan untuk aktifitas keseharian baik perseorangan maupun perkantoran hal ini sebagai rekomendasi untuk dipilih sebagai keputusan utama mempunyai reputasi baik bahkan terbaik[12].

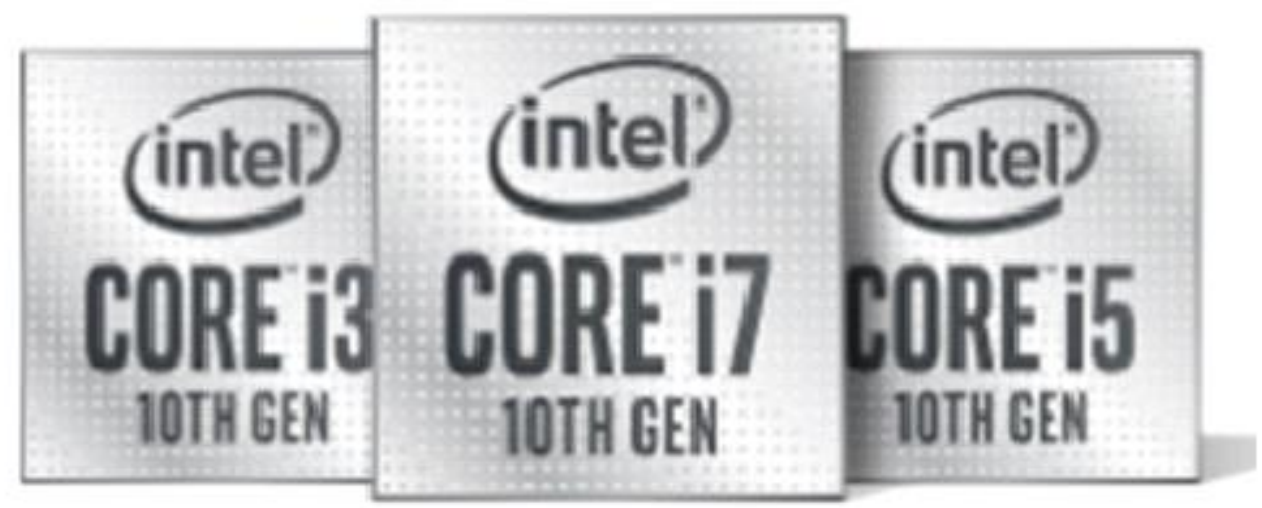

Gambar 5. 3 Jenis type prosessor i3 ,i5, i7 yang berbeda pada pengujian Central Prosessing Unit (CPU).

Jenis type prosessor antara lain: i3, i5, i7 ke tiga (3) jenis prosessor memiliki kemampuan masing-maing setiap prosessor keluaran generasi ke sepuluh (10) sebagaimana ditampilkan pada gambar 5[14].

\subsection{Pengumpulan informasi dan data.}

Salah satu upaya peningkatan mutu yaitu mengumpulkan data, analisis, observasi lapangan tetap sebagai acuan setiap penelitian.Untuk ukuran serta varian prosessor akan dipilih keluaran perusahaan Intel yang akan dibenchmark[15]. Adapun oranisasi avarge system performance yang telah melakukan pengujian terhadap 2 jenis varian generasi sebelumnya pada gambar 6.

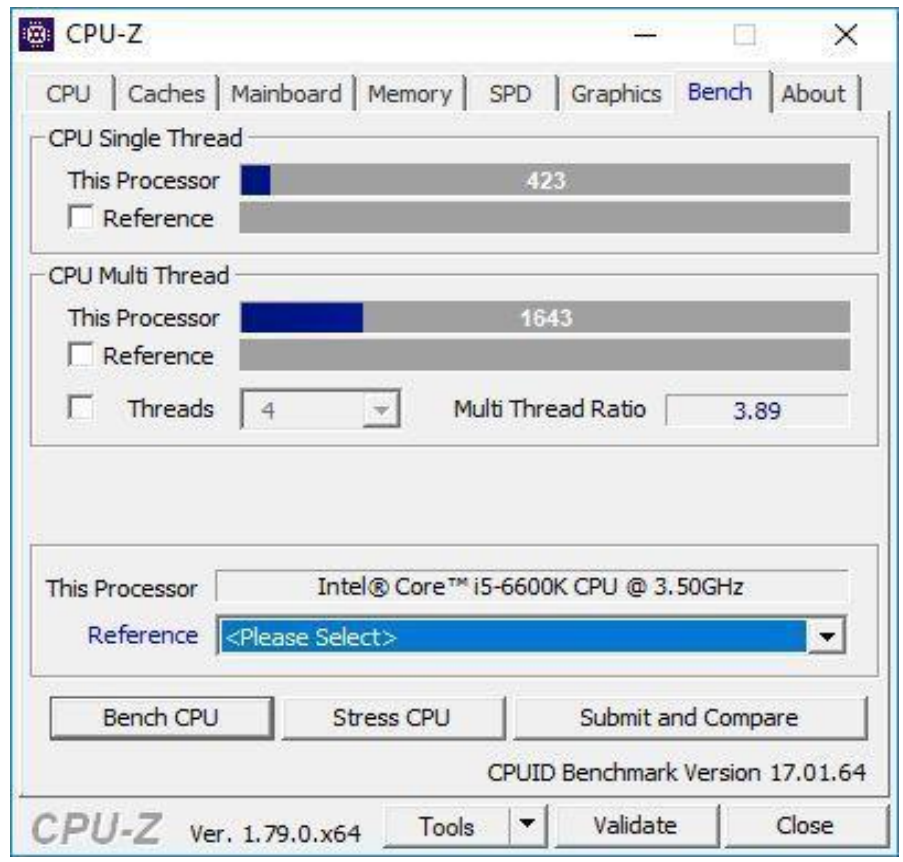

Gambar 6. Benchmark dari AnandTech survei market atau pasar Internasional.

Sumber benchmark oleh CPU-Z, pengujian pada yang bawah intel pentium Intel Core i5, 3.50 GHz sampai intel core i5 generasi sebelumnya Sebagaimana pada gambar 6. 


\subsection{Analisis hasil.}

Pengujian tahap pertama pada central prosessing unit dengan processor i3:

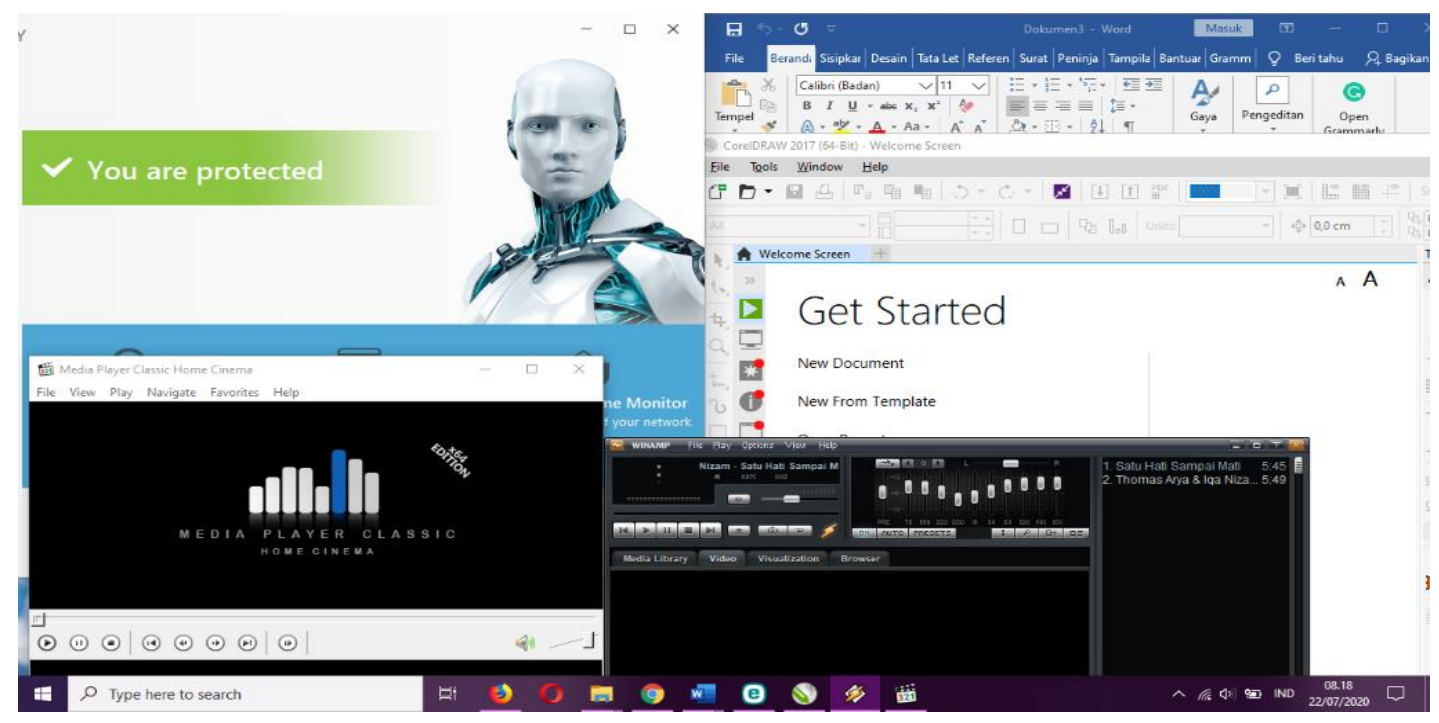

Gambar 7. Pengujian pada 5 jenis software aplikasi.

Software aplikasi yang digunakan sebagai penelitian ini menggunakan: Anti Virus Es Et Internet Security, Windows media player classic, Winamp, Microsoft office 2016, Coreldraw. Grafik 1 merupakan Grafik dari sistem operasi yang menunjukkan proses kerja prosessor core i3 sebagaimana terdapat pada gambar 7.

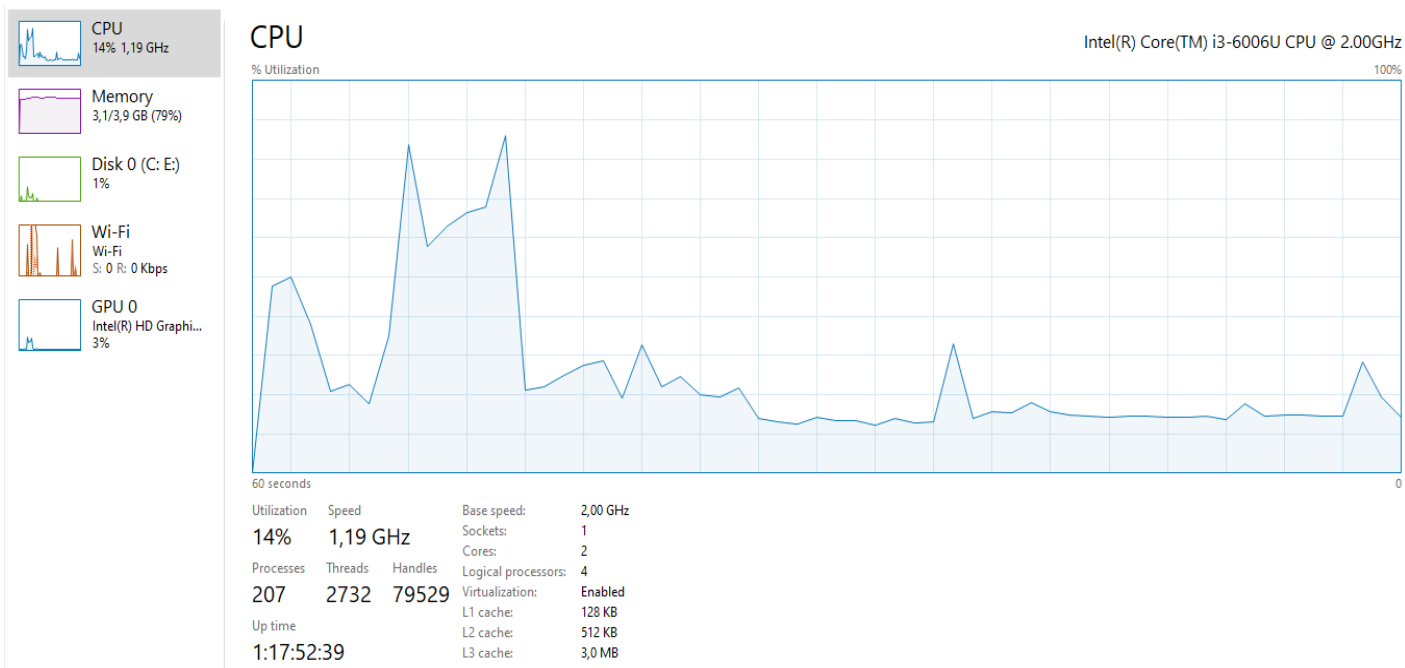

Gambar 8. Menunjukkan central prosessing unit (CPU) bekerja dengan kecepatan 1,19 Ghz.

Proses kerja yang sedang berlangsung secara realtime Analisa performance central processing unit (CPU) mendeteksi kerja prosessor Intel core i3 yaitu pada posisi setup login: $C P U=1,19 \mathrm{Ghz}$, Memori = 3,1 Ghz, Disk =1\%, Netwok=7,7 Mbps, GPU / kartu grafik = $3 \%$, Power use=low / 12 volt, Sebagaimana terdapat pada gambar 8. 
Tabel 1. Pengujian pada prosessor core i3

\begin{tabular}{|c|c|c|c|c|c|c|c|}
\hline \multirow[t]{2}{*}{ No. } & \multirow{2}{*}{$\begin{array}{c}\text { Jenis } \\
\text { Pengujian }\end{array}$} & \multicolumn{5}{|c|}{ Penggunaan Perangkat Keras/ Hardware } & \multirow{2}{*}{$\begin{array}{c}\text { Jenis } \\
\text { Prosessor }\end{array}$} \\
\hline & & CPU & Ram & Uses Disk & $\begin{array}{c}\text { Uses VGA/ } \\
\text { GPU }\end{array}$ & $\begin{array}{l}\text { Power } \\
\text { Suplay }\end{array}$ & \\
\hline 1 & $\begin{array}{l}\text { Media } \\
\text { Player } \\
\text { Clasic }\end{array}$ & $16 \%$ & $156 \mathrm{Mb}$ & $0.3 \mathrm{Mb}$ & $10.6 \%$ & Low & Core i3 \\
\hline 2 & Anti Virus & $45 \%$ & $19.7 \mathrm{Mb}$ & $0 \mathrm{Mb}$ & 0 & V.Low & \\
\hline 3 & $\begin{array}{l}\text { Corel } \\
\text { Drow }\end{array}$ & $0.45 \%$ & $173 \mathrm{Mb}$ & $0 \mathrm{Mb}$ & 0 & V.Low & \\
\hline 4 & Winamp & $32 \%$ & $36.6 \mathrm{Mb}$ & $0.1 \mathrm{Mb}$ & 0 & V.Low & \\
\hline 5 & Ms. Office & $53 \%$ & $82.2 \mathrm{Mb}$ & $1 \mathrm{Mb}$ & 1 & V.Low & \\
\hline
\end{tabular}

Sumber: Hasil pengujian benchmark terhadap 5 aplikasi yang berjalan secara Real-Time menggunakan central prosessing unit (CPU) prosessor i3[13].

\section{Prosessor intel core i3 :}

Non supot Hyper-Treading, Suport turbo boost dengan maksimum overclock pada range 2.933 Ghz sampai 3.2 Ghz. Suport clock graphic prossor $100 \mathrm{Mhz}$, Suport L3 Cache $4 \mathrm{Mb}$, Suport LGA Soket 1156, Suport prosessor core i3 dapat mengintergrasikan Virtuallizing technologi GPU ( Graphic Prosessor Unit) sehingga bekerja lebih kencang.

Prosessor Core i3 memiliki 2 prosessor (Dual Core). Kedua prosessor tersebur memiliki kelebihan yaitu melakukan 2 instruksi sekaligus dalam satu waktu.

\section{Pengujian tahan kedua pada central prosessing unit (CPU) dengan processor i5:}

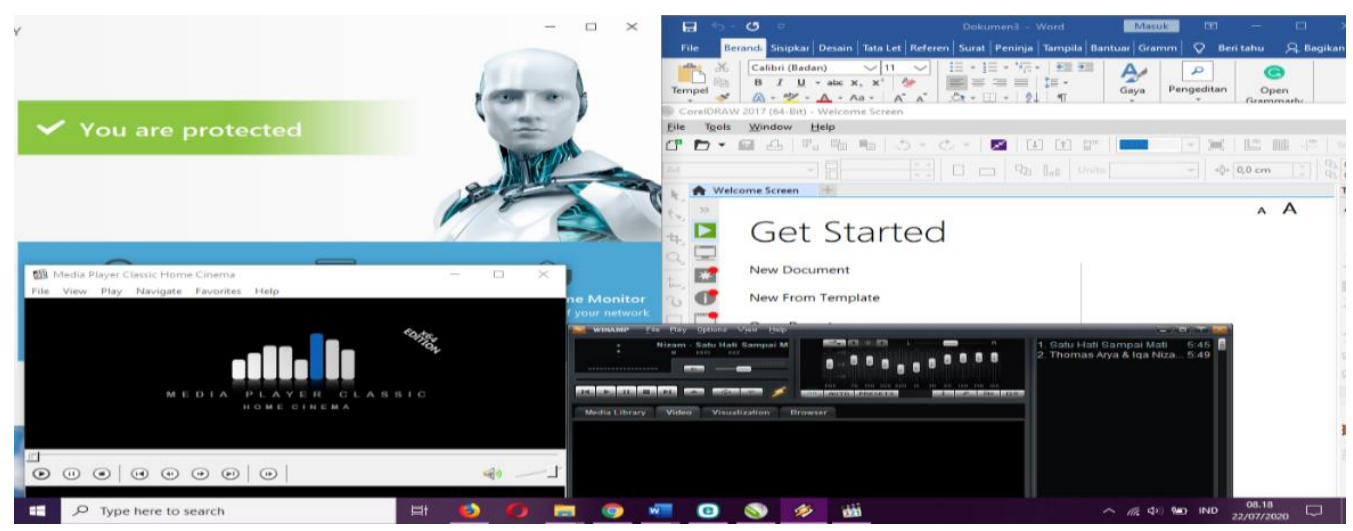

Gambar 8. Pengujian pada 5 jenis software aplikasi.

Software aplikasi yang digunakan sebagai penelitian ini menggunakan: Anti Virus Es Et Internet Security, Windows media player classic, Winamp, Microsoft office 2016, Coreldraw. Grafik 1 merupakan Grafik dari sistem operasi yang menunjukkan proses kerja prosessor core i5 sebagaimana terdapat pada gambar 8, Grafik 2. Grafik dari sistem operasi yang menunjukkan proses kerja prosessor core i5. 


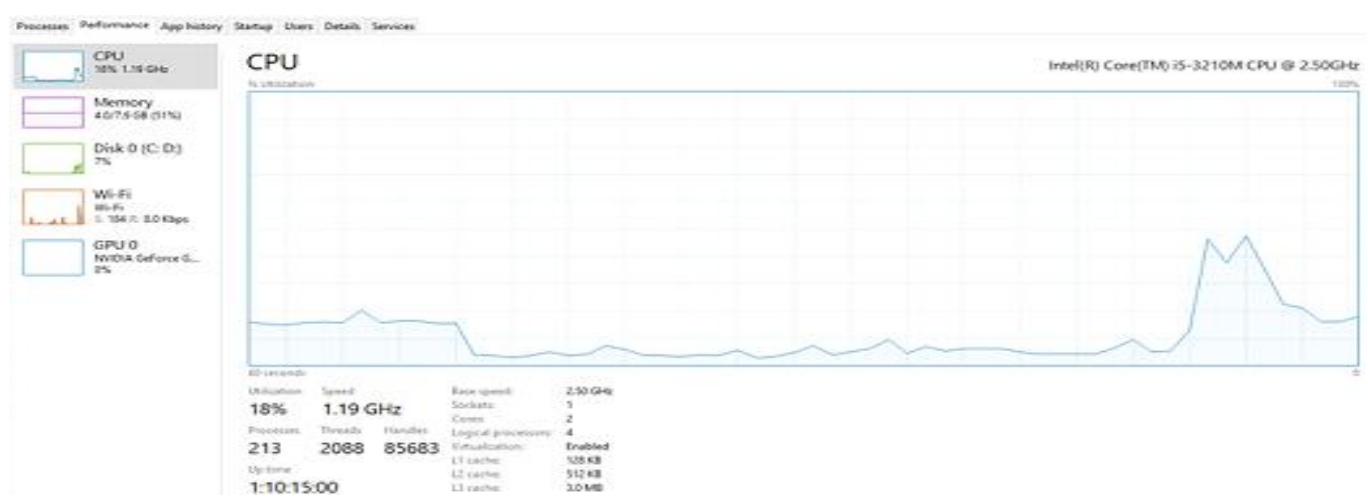

Gambar 9. Grafik menunjukkan central prosessing unit bekerja dengan kecepatan 1,19 Ghz.

Proses kerja yang sedang berlangsung secara realtime Analisa performance central processing unit (CPU) mendeteksi kerja prosessor Intel core i5 yaitu pada posisi setup login: CPU = 1,19 Ghz, Memori = 4,2 Ghz, Disk = 4 \%, Netwok = 7,7 Mbps, GPU / kartu grafik = $0 \%$, Power use = low / 12 volt, Sebagaimana terdapat pada gambar 9.

Tabel 2. Pengujian pada prosessor core i5

\begin{tabular}{|c|c|c|c|c|c|c|c|}
\hline \multirow[t]{2}{*}{ No. } & \multirow{2}{*}{$\begin{array}{c}\text { Jenis } \\
\text { Pengujian }\end{array}$} & \multicolumn{5}{|c|}{ Penggunaan Perangkat Keras / Hardware } & \multirow{2}{*}{$\begin{array}{c}\text { Jenis } \\
\text { Prosessor }\end{array}$} \\
\hline & & $C P U$ & Ram & Uses Disk & $\begin{array}{c}\text { Uses } \\
V G A / \\
G P U\end{array}$ & $\begin{array}{l}\text { Power } \\
\text { Suplay }\end{array}$ & \\
\hline 1 & $\begin{array}{l}\text { Media } \\
\text { Player } \\
\text { Clasic }\end{array}$ & $16 \%$ & $156 \mathrm{Mb}$ & $0.3 \mathrm{Mb}$ & $10.6 \%$ & Low & Core i5 \\
\hline 2 & Anti Virus & $45 \%$ & $19.7 \mathrm{Mb}$ & $0 \mathrm{Mb}$ & 0 & V. Low & \\
\hline 3 & $\begin{array}{l}\text { Corel } \\
\text { Drow }\end{array}$ & $0.45 \%$ & $173 \mathrm{Mb}$ & $0 \mathrm{Mb}$ & 0 & V. Low & \\
\hline 4 & Winamp & $32 \%$ & $36.6 \mathrm{Mb}$ & $0.1 \mathrm{Mb}$ & 0 & V. Low & \\
\hline 5 & Ms. Office & $53 \%$ & $82.2 \mathrm{Mb}$ & $1 \mathrm{Mb}$ & 1 & V. Low & \\
\hline
\end{tabular}

Sumber: Hasil pengujian benchmark terhadap 5 aplikasi yang berjalan secara Real-Time menggunakan central prosessing unit (CPU) prosessor i5.

\section{Prosessor intel core i5}

Suport hyper-treading, Terdapat 2 Prosessor (dual-core). Prosessor core i5 juga memiliki fersi prosessor quad core, Suport turbo boost maxsimum overclock pada $2.4 \mathrm{Ghz}$ sampai $3.33 \mathrm{Ghz}$, Supot L3 Cache 4-8 Mb, Suport LGA Socket 1156, Suport Intel Hd Graphics, Suport Maximal Ram 16 Gb. Prosessor Core i5 terdapat Dual-Core. Namun ada pula Core i5 yang terdiri dari prosessor Quad Core namun tidak di lengkapai dengan teknologi hyper-Treading. 


\section{Pengujian tahan kedua pada central prosessing unit (CPU) dengan processor i7:}

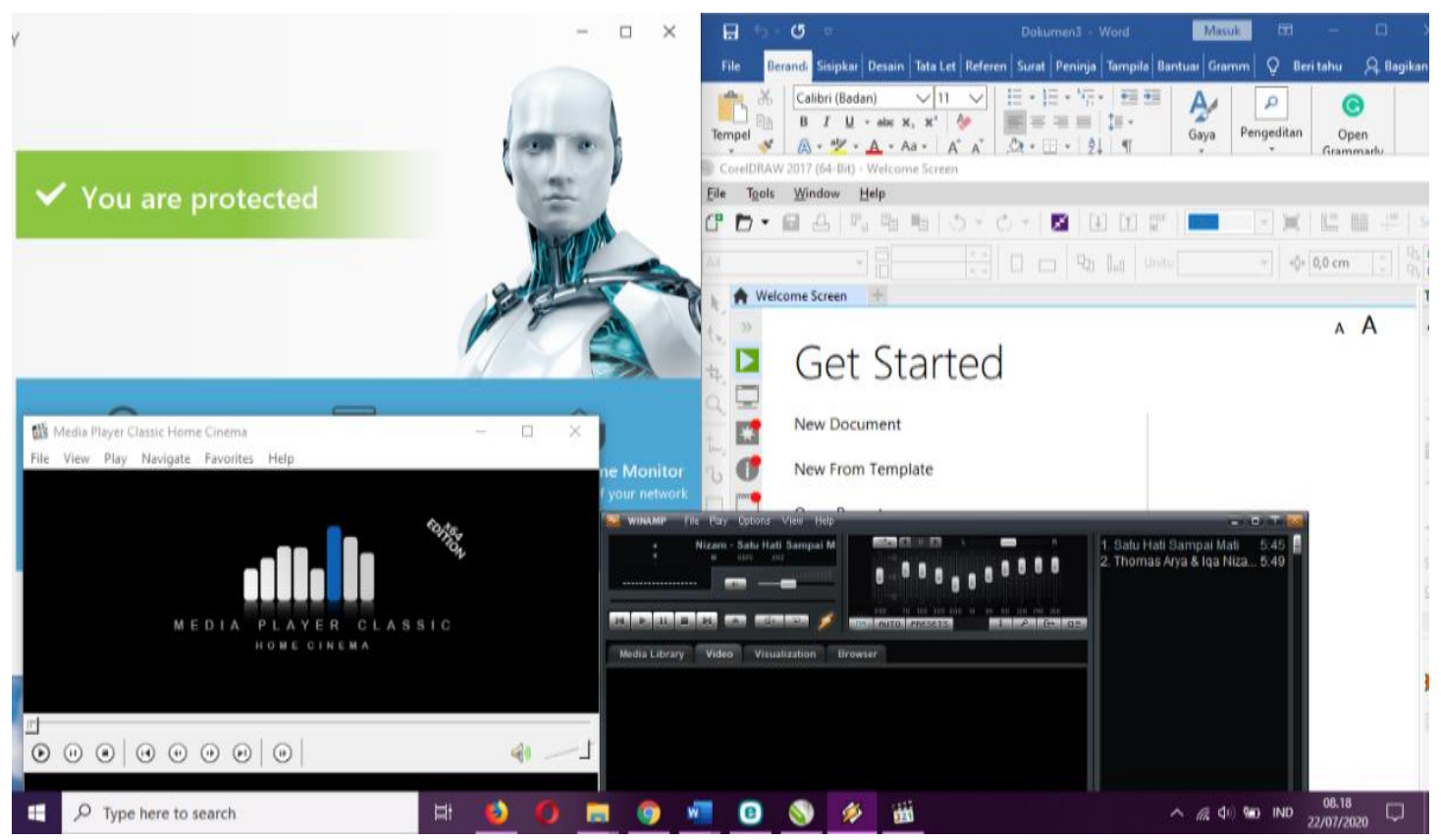

Gambar 10. Pengujian pada 5 jenis software aplikasi.

Software aplikasi yang digunakan sebagai penelitian ini menggunakan: Anti Virus Es Et Internet Security, Windows media player classic, Winamp, Microsoft office 2016, Coreldraw. Grafik 1 merupakan Grafik dari sistem operasi yang menunjukkan proses kerja prosessor core i7 sebagaimana terdapat pada gambar 10.

Software aplikasi yang digunakan sebagai penelitian ini menggunakan: Anti Virus Es Et Internet Security, Windows media player classic, Winamp, Microsoft office 2016, Coreldrow.

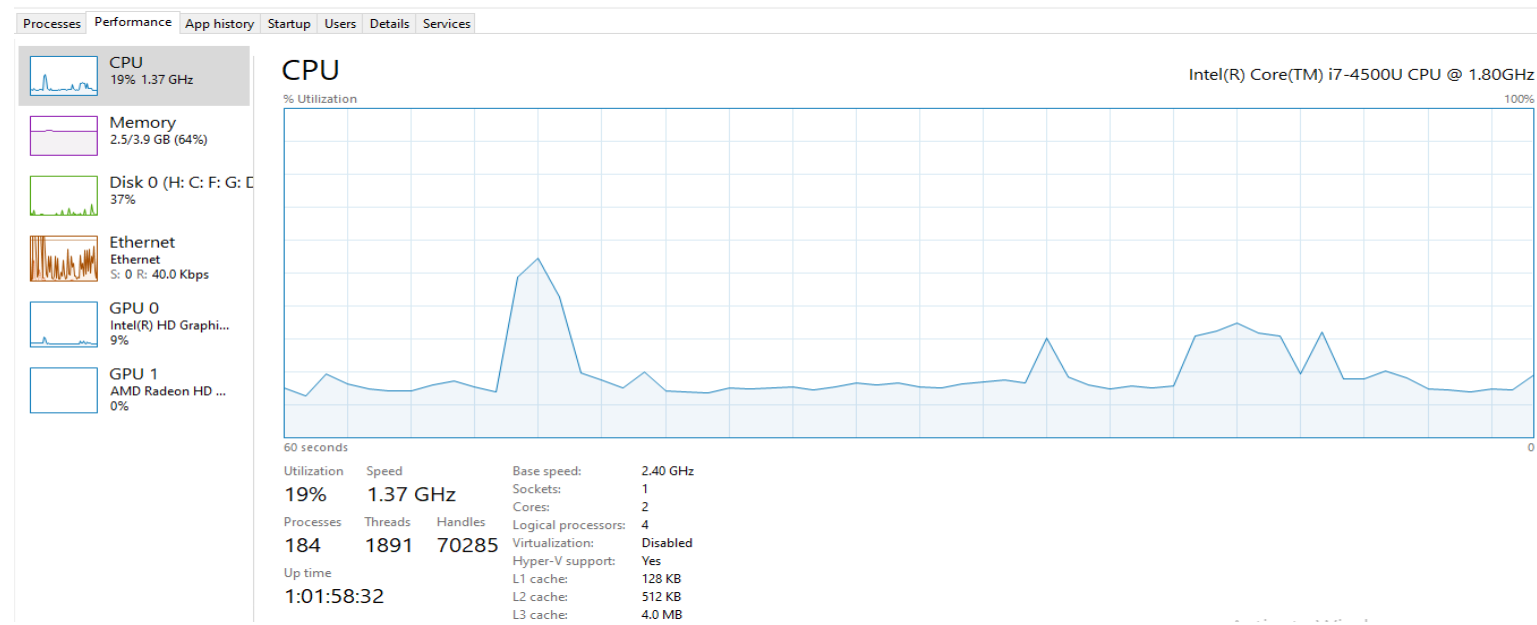

Gambar 11. Grafik dari sistem operasi yang menunjukkan proses kerja prosessor core i7.

Proses kerja yang sedang berlangsung secara realtime Analisa performance central processing unit (CPU) mendeteksi kerja prosessor Intel core 77 yaitu pada posisi setup login: CPU = 1, 27 Ghz, Memori = 3,9 Ghz, Disk = $37 \%$, Netwok = 40 kbps, GPU / kartu grafik = 9\%, Power use = low / 12 volt, Sebagaimana terdapat pada gambar 11. 
Tabel 3. Pengujian pada prosessor core i7

\begin{tabular}{|c|c|c|c|c|c|c|c|}
\hline \multirow[t]{2}{*}{ No. } & \multirow{2}{*}{$\begin{array}{c}\text { Jenis } \\
\text { Pengujian }\end{array}$} & \multirow[b]{2}{*}{$C P U$} & \multicolumn{4}{|c|}{ Penggunaan Perangkat Keras / Hardware } & \multirow{2}{*}{$\begin{array}{c}\text { Jenis } \\
\text { Prosessor }\end{array}$} \\
\hline & & & Ram & Uses Disk & $\begin{array}{l}\text { Uses VGA/ } \\
\quad \text { GPU }\end{array}$ & $\begin{array}{l}\text { Power } \\
\text { Suplay }\end{array}$ & \\
\hline 1 & $\begin{array}{c}\text { Media Player } \\
\text { Clasic }\end{array}$ & $16 \%$ & $156 \mathrm{Mb}$ & $0.3 \mathrm{Mb}$ & $10.6 \%$ & Low & Core i7 \\
\hline 2 & Anti Virus & $45 \%$ & $19.7 \mathrm{Mb}$ & $0 \mathrm{Mb}$ & 0 & V. Low & \\
\hline 3 & Corel Drow & $0.45 \%$ & $173 \mathrm{Mb}$ & $0 \mathrm{Mb}$ & 0 & V. low & \\
\hline 4 & Winamp & $32 \%$ & $36.6 \mathrm{Mb}$ & $0.1 \mathrm{Mb}$ & 0 & V. low & \\
\hline 5 & Ms. Office & $53 \%$ & $82.2 \mathrm{Mb}$ & $1 \mathrm{Mb}$ & 1 & V.Low & \\
\hline
\end{tabular}

Sumber: Hasil pengujian benchmark terhadap 5 aplikasi yang berjalan secara Real-Time menggunakan central prosessing unit (CPU) prosessor i7.

\section{Prosessor intel core i7}

Supot hyper-treading, Suport Tubo-boost maksimum overclocking otomatis berkisar antara 1.73 Ghz sampai 3.33 Ghz , Suport L3 Cache 8-12 Mb, Perusahaan intel QuickPath Interconnet memiliki fungsi untuk mempercepat proses pembacaan data mencapai $\quad 25.6 \mathrm{gb} /$ detik, Suport LGA Socket 1156, Suport intel HD Graphics, Suport maximal Ram sebesar 24 Gb.

\section{Prosessor intel core i7}

Prosessor intel core i7 memiliki 4 prosessor quad core mampu bekerja pada kecepatan $3.07 \mathrm{Ghz}$. memiliki kemampuan lebih seperti sistem kerja besar pengolahan data, memiliki daya tahan panas yang cukup baik, akan tetapi besar daya yang digunakan.

\section{KESIMPULAN.}

kesimpulan dari pengujian pada Prosessor Intel $i 3, i 5, i 7$ pada dasarnya merupakan prosessor yang sama yaitu $i 7$. Akan tetapi apabila jika ada inti atau fitur yang tidak bekerja maka akan di jadikan produksi yang lebih rendah dari asalnya i7, menjadi i5, jika banyak inti yang tidak bekerja maka produksi akan melabeli dengan produk yang lebih rendak seperti i3. Metode ini menggunakan metode bechmark, yang mangacu pada lima aspek teknik perbandingan, analisis performance central prosessing unit (CPU), unit produksi terbaik, tindakan atau keputusan yang diambil dalam pemilihan hardware serta software yang kompetibel. Benchmark ini berhasil melakukan pengujian pada hardware central prosessing unit (CPU) dengan 3 (tiga) type antara lain prossessor i3, prossessor i5, prossessor i7. Tahap pengujian menemukan 6 (enam) kategori yang berbeda yaitu prosessor i3 membutuhkan 3, 1 GB untuk setup login pada 1 user, prosessor i5 membutuhkan 4,2 GB saat setup login 1 user program login, sedangkan prosessor i7 membutuhkan 2,5 GB saat setup login pada 1 user central prosessing unit (CPU). Untuk hasil pengujian yang dilaksanakan pada cental prosessing unit (CPU) penggunaan ram oleh prosessor i3 sebesar $3.1 \mathrm{~Gb}, \mathrm{GPU}$ $3 \%$, Disk uses 1\%, penggunaan network atau jaringan 7.7 Mbps, penggunaan power suplay very low. Prosessor i5 sebesar 4.2 $\mathrm{Gb}, \mathrm{GPU} 0 \%$, Disk uses 0\%, penggunaan network atau jaringan 7.7 Mbps, penggunaan power suplay low. Prosessor i7 sebesar $2.5 \mathrm{~Gb}$, GPU 9\%, Disk uses 9\%, penggunaan network atau jaringan $104 \mathrm{Kbps}$, penggunaan power suplay high.

\section{UCAPAN TERIMA KASIH}

1. Terimakasih saya ucapkan kepada pengelola Journal Matrik yang telah memberikan kesempatan bisa berpartisipasi dalam publikasi Journal.

2. Terimaksih pula saya ucapkan kepada : 4N6Labs TIM, Universitas Teknologi Sumbawa (Fakultas Teknik), Kelas Pagi Yogyakarta (KPY), Tim CyberComunity 4N6labs Region Bima \& Dompu, Perusahaan Intel.Corp, Benchsmark App. 


\section{REFERENSI}

[1] S. Sunter and P. Sarson, “A / MS Benchmark Circuits for Comparing Fault Simulation , DFT , and Test Generation Methods, ” IEEE Internasional Test Confrence. Vol. 1, No. 2 , PP. 1- 72017.

[2] P. Kotsampopoulos, Dimitris Lagos, H. Nikos, M. Omar Faruque, L. Georg, N. Onyi, F. Paul, S. Michael, F. Ponci, A. Monti, V. Dinacahi, Kai Strunz. “A Benchmark System for Hardware-in-the-Loop Testing of Distributed Energy Resources, ” IEEE Power Energy Technol. Syst. J., Vol. 5, No. 3, PP. 94-103, 2018.

[3] Blesson Varghese, Ozgur Akgun, Ian Miguel, Long Thai and Adam Barker."Cloud Benchmarking For Maximising Performance of Scientific Applications" IEEE Transactions on Cloud Computing. Vol. 7, No. 1, PP. 1-14, 2016.

[4] Konstantinos Chasapis, Jean- Yves Vet, Jean- Thomas Acquaviva. "Benchmarking Parallel File System Sensitiveness to I/O Patterns" IEEE Internasional Symposium on Modeling, Analysis and Simulation of Computer and Telecomunication System. Vol. 27. No. 1, PP. 427 - 428, 2019.

[5] Andrew S. Morgan, kaiyu Hang, Walter G. Bircher, Fadi M. Alladkain, Abhinav, Gandhi, Berk Calli, Aaron M. Dollar. "Benchmarking Cluttered Robot pick-and-Place Manipulation With the Box and Blocks Test ," IEEE Robotics and Automation Letters Vol. 5, No. 2, PP. 1-8, 2020.

[6] S. Sidhanta, S. Mukhopadhyay, and W. Golab, “Dyn-YCSB : Benchmarking Adaptive Frameworks, ” 2019 IEEE World Congr. Serv., Vol. 2642-939X, PP. 392-393, 2019.

[7] Beau Potre, Brett R. Cowan, Edward DiBella, Sancgeetha Kulaseharan, Devavrat Likhite, Nils Noorman, Lennart Tautz, Nicholas Tustison, gert Wollny, Alistair A. Young, Avan Suinesiaputra. "An Open Benchmark Challenge for Motion Correction of myocardial Perfusion MRI,” IEEE. Vol. 21, No. 5, PP. 1-12, 2017.

[8] Rui Han, Lizy Kurian John, Jianfeng Zhan. “Benchmarking Big Data System: A Review” IEEE Transaction on Services Computing. Vol. 11, No. 3 , PP. 1-18, 2018.

[9] Peter Eckert, Auke J. Ijspeert “Benchmarking Agility For Multilegged Terrestrial Robots, ”IEEE Transactions On Robotics. Vol. 35, No. 2 , PP. 1-7, 2019.

[10] Sebastian Gallenm“uller, Stephan G“unther, Maurice Leclaire , Samuele Zoppi , Fabio Molinari Richard Sch“offauer , Wolfgang Kellerer, Georg Carle "Benchmarking Networked Control Systems," IEEE Workshop on Benchmarking Cyber-Physical Networks and Systems. Vol. 1 , No. 2 , PP.7-12, 2018.

[11] Xuheng Duan, Haochen Pan, Lewis Tseng, Yingjian Wu..” BBB : Make Benchmarking Blockchains Configurable and Extensible" IEEE Pacific rim Internasional Symposium on Dependable Computing.Vol. 24 , No.1 , PP. 61 - 62, 2019.

[12] Raquel Almeida, Henrique Madeira “Evolving from Dependability to Resilience Benchmarks : Issues and Possibilities, ”IEEE LatinAmerican Symposium on Dependable Computing. Vol. 7 , No. 1 ,PP. 127-130, 2016.

[13] P. Studi, T. Elektro, F. Teknik, and U. Muhammadiyah, “Analisis Kinerja Prosesor terhadap Proses Overclocking dan Downclocking," Vol. 1, No. 1, PP. 7-12, 2019.

[14] A. Karki, C. P. Keshava, and S. M. Shivakumar, “Tango : A Deep Neural Network Benchmark Suite for Various Accelerators, ”IEEE Int. Symp. Perform. Anal. Syst. Software.,Vol. , No. , PP. 137-138, 2019.

[15] Lin Li, Alfredo Alan Flores Saldivar, Yun Bai, Yi Chen, Qunfeng Liu, Yun Li "Benchmarks for Evaluating Optimization Algorithms and Benchmarking MATLAB Derivative-Free Optimizers for Practitioners 'Rapid Access," IEEE Access, Vol. 7,No. PP. 7965779670, 2019. 
Matrik : Jurnal Manajemen, Teknik Informatika, dan Rekayasa Komputer,

Vol. 20, No. 2, Mei 2021: 237 248 